\title{
Percussion Pattern of Terebang Gede in Panggung Jati Studio, Panggung Jati Village, Serang
}

\author{
Suhaya Suhaya ${ }^{1 凶}$, Abdul Rachman ${ }^{2}$, Syahrul Syah Sinaga², \\ Dandi Musa Alfayad ${ }^{1}$
}

${ }^{1}$ Universitas Sultan Ageng Tirtayasa, Indonesia

${ }^{2}$ Universitas Negeri Semarang, Indonesia

Submitted: February 11, 2020. Revised: September 29, 2020. Accepted: November 4, 2020

\begin{abstract}
The characteristics of a region become an identity that is certainly inseparable from the noble values it adheres to, including religious values as the foundation for the formation of art of terebang gede in the Panggung Jati studio, Panggung Jati village, Serang, Banten. This study aims to describe the percussion patterns in the art of Terebang Gede both in text and context by using a qualitative paradigm with descriptive analytical methods. As a highlighted theory, ethnomusicology is used to analyze the existence of music in a culture, both from physical aspects and socio-cultural aspects. The data collection technique is done by interview, documentation study, and literature study. The data analysis stages are carried out in the order of data collection, data reduction, data organizing into a pattern, category, and description into basic descriptions that lead to the concluding process. The results showed that the percussion pattern of terebang gede is very simple. The percussion patterns on all existing musical instruments, such as the musical instrument of koneng, kempul, penganak (bibit), interlude, and bass (terebang gede), still follow the framework of the percussion "standard" which is hereditary from previous generations. Until now, this accompaniment without the development of rhythmic variations has been used to accompany syair or sholawat Al-Barzanjiwith with tones of Sundanese-style songs of the salendro type. Changes in accompaniment were not made because this performance was only performed on special occasions for Muslims to broadcast and support worship which was not intended as entertainment music.
\end{abstract}

Keywords: art; music; percussion patterns; terebang gede

How to Cite: Suhaya, S., Rachman, A., Sinaga, S. S., \& Alfayad, D. M. (2020). Percussion Pattern of Terebang Gede in Panggung Jati Studio, Panggung Jati Village, Serang. Harmonia: Journal of Arts Research And Education, 20(2), 223-230

\section{INTRODUCTION}

Banten is the 33rd province in Indonesia, which is a province resulting from the expansion of the province of West Java following the Decree of Law No. 23 of 2000. Banten is a new province that was born from West Java culture; this can also be seen through its arts who still follow or have their roots in Sundanese culture (Peraturan Gubernur Banten Tentang Rencana Kerja Pemerintah Daerah Provinsi Banten Tahun 2017, 2017; Mulyana, 2001).

Banten Province, acculturationally, has cultural diversity, especially in terms of traditional arts which are inherited from their ancestors from generation to generation. The existence of this typical Banten

\footnotetext{
Corresponding author:

E-mail: suhaya72puri@untirta.ac.id
} 
cultural heritage has an important role for society, including as an identity in showing the characteristics of an area. The elements that make up a community such as a language, religion, history, art, customs, traditions, and norms, reflect the culture in each ethnic group, including the people of Banten. This is reinforced by the statement that every community must have the same cultural values brought from the past (Said, 2016; Nurhasanah \& Maryuni, 2012; Widyasari, 2014).

Apart from the similarity of these elements, of course, there are variations in the cultural structure of each existing community. Therefore, in the context of art, at its development stage, it is often used as a distinctive and traditional identity that is owned by the community itself and grows in an artistic environment that is different from one another (Wicaksono, 2019).

Along with the times marked by the rapid development of information technology and the global market, people's interest in maintaining cultural heritage as an identity in shaping the character of the nation has experienced a massive decline. The attachment of digitalization to every aspect of human life today is one of the factors of the moral and ethical crisis in the current generation. It will even result in the elimination of existing traditional arts if conservation efforts are not made through interesting platforms that keep up with the times (Harjono \& Rachman, 2018; Rachman \& Pribadi, 2019; Rachman \& Utomo, 2018, 2019; Simeon, 2015; Simeon et al., 2017; Zahrotul \& Rachman, 2020).

The music of terebang gede is an art that grew and developed during the spread of Islam in Banten and was seen as new teaching among the people at that time. The music of terebang gede as the folk art was brought by a guardian named Syarif Hidayatullah with the title Sunan Gunung Jati, who was the first person to spread Islam in West Java and Banten at that time with the help of his students (Fauzan \& Nashar, 2017; Nugraha, 2018; Viedar, 2018). Rebana (tambourine) or terebang is waditra type of leather percussion instrument, played by tapping it with the palm. The function of Waditra is as a rhythm presenter whose sound is atonal. Tambourine or terebang is a waditra that is incorporated in genjring, rudat, gemyung, tagoni, qasidah, and others (Kubarsah, 1994; Sinaga, 2001).

The function of music is as a communication medium in conveying good values through melodies and song lyrics from music composers to listeners. Dalori et al. (2019) explain the function of music, including as a communication tool that applies in a culture, containing certain signals that are only known and understood by those who support that culture. In the context of tambourine music, signs and messages are found in song melodies, poems, or song lyrics that contain religious values as beliefs and values about politeness or norms.

At this time, the art of terebang gede among the people of Banten is only played and preserved by the elders. The lack of interest of the younger generation in studying the music of terebang gede has contributed to the erosion of cultural heritage, especially in the knowledge of traditional percussion patterns of terebang gede. One of the factors that influence the lack of interest of the younger generation in studying the music of terebang gede is the lack of literacy or teaching materials that include the percussion pattern of terebang gede. Therefore, education through music terebang gede can be an effort to improve the existence of local wisdom at the global level.

Efforts to incorporate traditional music into local curriculum material content are also an effective cultural dissemination effort. Moreover, if it is accompanied by creative efforts through broader performances such as cultural tourism performances, the distribution and the existence of traditional music will be maintained (Suprihatin \& Pratamawati, 2019).

The phenomenon seen in the learning process at the formal and non-formal levels as a form of preservation is still dominated by the learning of western musical instruments such as pianica, violin, guitar, recorder, keyboard, and others. Whereas if there is traditional music learning, the 
musical instruments usually used still use musical instruments outside the local heritage of the local area.

Hood (1957) said that ethnomusicology is a field study that the object of the research is on the art of music as a physical, psychological, aesthetic, and cultural phenomenon. Based on this, the researchers felt the need to conduct an ethnomusicological study related to the percussion pattern on the instrument of terebang gede, as a parameter of the younger generation's understanding of the regional traditional art culture.

Referring to the background above, the research on the music of terebang gede aims that the music of terebang gede can be known and understood deeply by the local community in particular, the wider community, and the world of education in general. Besides, it is an effort to preserve traditional arts to remain sustainable during the ever-changing Banten society.

Studying music is inseparable from the aspects of the text related to percussion patterns, and contexts related to aspects outside the percussion patterns such as society, history, and others. The study of percussion patterns both from rhythmic, tempo, and play will help in assessing the character values contained in the music of terebang gede. Research related to the problem of percussion patterns in the music of terebang gede has been quite a lot done by previous researchers which of course have a different problem focus.

Research conducted by Khasbullah et al. (2005) Research conducted by Khasbullah et al. (2005) revealed the problem of percussion patterns that had not been written in western notation, as well as the uniqueness of the traditional percussion instrument pattern "tar" both in text and context. The findings show that there are 20 traditional "tar" percussion patterns used to initiate the art of hadrah which consists of three stages, namely gencat, terosan, and marade, which have a percussion pattern in the form of literal repetition.

Research conducted by Nugraha (2018) reveals that the structure of the te- rebang gede art performance is a routine in commemoration of the birthday of the Prophet Muhammad SAW, which is a tradition in the Serang community. The research was studied using the interpretive qualitative analysis research method, which uses the science of interpretation related to folklore.

In some of the previous studies above, it can be ascertained that the focus point of the research is different. Therefore, this study aims to analyze the percussion patterns studied using the discipline of ethnomusicology to analyze the text and context in the music of terebang gede.

\section{METHOD}

This research was conducted at Panggung Jati Studio, RT 01/RW 03, Taktakan District, Serang City, Banten, Indonesia. The research was conducted using descriptive-analytical methods in a qualitative paradigm with an ethnomusicology approach. This method was chosen because it is considered more suitable to be used to study a phenomenon in natural object conditions, where the researcher acts as a key instrument.

Data were collected using techniques of interview, documentation study, and literature study. Data analysis was carried out inductively which emphasizes finding meaning rather than generalizing (Sugiyono, 2016). The data analysis stages are carried out in the order of data collection, data reduction, data organizing into a pattern, category, and description into a basic description leading to the concluding process (Moleong, 2017).

\section{RESULTS AND DISCUSSION}

\section{The Music of Terebang Gede in Panggung Jati Studio}

The Music of terebang gede in Panggung Jati Studio estimated to have existed since the time of the empire of Sultan Ageng Tirtayasa in 1650-1651s. The studio was originally led by $\mathrm{H}$. Afandi Kamal, who died in 1692, then continued by des- 
cendants of the leaders of the Panggung Jati Studio, such as (1) Mr. Nali, the second generation; (2) Mrs. Kunti, the third generation; (3) Mr. Darab, the fourth generation; (4) Mr. Sanudin, the fifth generation; and (5) Mr. Asmad, the sixth generation. Until now, the leader of the Panggung Jati Studio has entered the 7th generation, which is led by H. Mistar.

Although time has gone up to seven generations, the functions of Terebang gede music in Panggung Jati village unchanged. It is proven that until now the music of terebang gede is still being preserved and developed in the Panggung Jati community. Its main function remains as a spiritual means that does not emphasize the entertainment aspect.

The efforts made by the members of the studio in maintaining the originality of the music of terebang gede aimed at making the next generation stick to the original culture which is full of character education. This is following the opinion of Ramadhani \& Rachman (2019) that efforts to maintain the originality of a pre-existing art are needed to maintain the cultural character of a nation.

The music of Terebang Gede is usually performed at big events such as welcoming big guests (ageung) who visit the Banten area, religious memorials such as muludan, rajaban, ruwutan rumah, and also at other events such as weddings, khitanan, and others.

Waditra/large musical instrument of terebang gede is made of jackfruit wood and sheepskin. The following are musical instruments used in the music of terebang gede which consists of several parts, namely:

Koneng, is a large musical instrument of terebang gede that has the smallest size compared to other instruments. This musical instrument has approximately $12 \mathrm{~cm}$ to $18 \mathrm{~cm}$ high, the width of the upper skin is about $20 \mathrm{~cm}$ to $22 \mathrm{~cm}$, and the width of the back circle of wood is about $14 \mathrm{~cm}$ to $15 \mathrm{~cm}$. The way to play a musical instrument koneng is to hit it with the palm. This musical instrument produces the sounds of tung and pak.

Kempul, is a musical instrument that has a higher size than koneng, which is 18 $\mathrm{cm}$ to $20 \mathrm{~cm}$. The circumference of the upper skin is $28 \mathrm{~cm}$ to $30 \mathrm{~cm}$, and the width of the back wooden circle is about $15 \mathrm{~cm}$ to $16 \mathrm{~cm}$. The way to play the kempul instrument is beaten with the palm. This musical instrument produces the sounds like tang and pak.

Penganak, is a musical instrument which has a height of $15 \mathrm{~cm}$ to $17 \mathrm{~cm}$, a width of the upper skin circumference of $40 \mathrm{~cm}$ to $42 \mathrm{~cm}$, and a width of the back wooden circle of $20 \mathrm{~cm}$ to $22 \mathrm{~cm}$. The way to play this instrument is beaten with the palm. This musical instrument produces the sound of dung, tang, and pak.

Sela, is a musical instrument with a height of $18 \mathrm{~cm}$ to $20 \mathrm{~cm}$, a width of the upper skin circumference of $43 \mathrm{~cm}$ to $45 \mathrm{~cm}$, and a width of the back wooden circle of 22 $\mathrm{cm}$ to $24 \mathrm{~cm}$. The way to play the musical instrument is beaten with the palm. This musical instrument produces the sounds like dung, tang, and pak.

Terebang Gede (Bass), is a musical instrument that has a height of $38 \mathrm{~cm}$ to 40 $\mathrm{cm}$, a width of the upper skin circumference of $66 \mathrm{~cm}$, and a width of the back wooden circle of $40 \mathrm{~cm}$ to $45 \mathrm{~cm}$. The way to play the musical instrument is beaten with a stick. This musical instrument produces the sound of der. The comparison of the size and shape of the five types of musical instruments is shown in Figure 1.

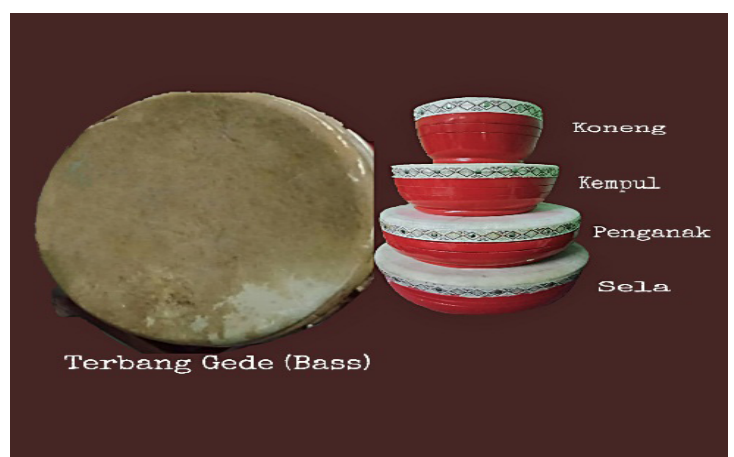

Figure 1. The form and size comparison of the musical instrument Terebang Gede 
Percussion Patterns of Terebang Gede in Panggung Jati Studio, Panggung Jati Village, Serang

The percussion pattern of the music of Terebang Gede has a very simple motif and distinctive. The standard of percussion patterns that have existed since then until now has not changed. This is in contrast to today's music, which is constantly evolving and changing dynamically following the demands of the fan community.

The songs of terebang gede that are performed at each performance are songs that use the poem Sholawat Al-Barzanji. Al-Barzanji is a literary work that contains messages that aim to arouse love and imitate the great Muslim lord, the Prophet Muhammad SAW. In Sholawat Al-Barzanji, the biography of the Prophet Muhammad SAW is contained from his birth to his death, as well as stories that describe the personal glory of the Prophet Muhammad SAW (Chusna, 2015; Khasanah et al., 2020).

The song of Sholawat Al-Barzanji, sung by the music group of Terebang Gede of Panggung Jati Studio, is sometimes interspersed with the notation system of Sundanese songs. For example, the song gaya and the song buah kawung that use the scale system salendro. This shows how closely a cultural element is related to the issue of a society's religious behavior. In this context, linkages can be in the form of group identities that are strengthened by religious identity or cultural identity in the form of ethnic identity, traditional local identity, or religious thought identity (Tri \& Haryanto, 2015).

The simplicity of percussion patterns of Terebang Gede on every type of music instrument, which until now retained, can be explained as follows.

\section{The Percussion Pattern of Koneng}

The musical instrument koneng has a very simple pattern, this is shown by the presence of a $1 / 4$ notation that fills in every beat that is carried out continuously and repeatedly. The region of the musical instrument Koneng is in the middle region, which is represented by the sound tung, and high, which is represented by the sound of tak. The following is the description of the percussion pattern rhythmic of koneng.

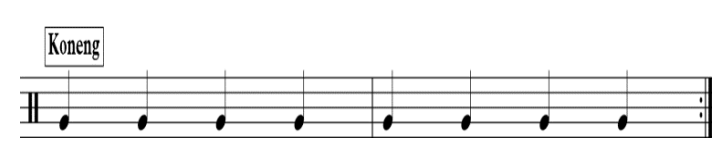

Figure 2. The percussion pattern of Koneng

Based on the notation above, we can see that the percussion pattern of koneng is very constant (monotonous) filling each beat as if it has a role in maintaining the beat or tempo.

\section{The Percussion Pattern of Kempul}

The percussion pattern of the musical instrument of Kempul compared with the musical instrument of Koneng seems more varied. The repeated percussion pattern were carried out in each rhythmic series along two bars. In the first bar, the percussion pattern of kempul is a large triol pattern that fills the first and second beat. On the second measure, the first beat is filled with two $1 / 8$ notes and the second beat is filled with a single $1 / 8$ note. The following is the description of percussion rhythmic of kempul.

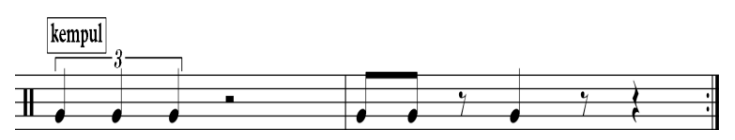

Figure 3. The percussion pattern of Kempul

\section{The Percussion Pattern of Penganak}

The musical instrument of penganak has the pattern more varied when compared with other instruments. The percussion pattern of the musical instrument of penganak consists of two bars that are played repeatedly. In the first bar, the musical instrument plays a combination notation of $1 / 8$ and $1 / 16$, while in the second bar, it plays a combination of notes of $1 / 4,1 / 8$, and $1 / 16$. The following is the description of percussion rhythmic of penganak.

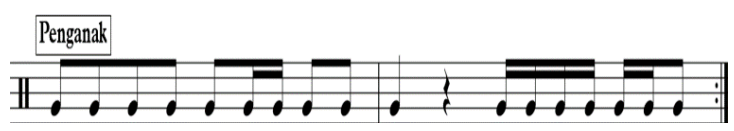

Figure 4. The percussion pattern of Penganak 
Based on the notation Figure 4, we can describe that in the first bar, the percussion pattern of the musical instrument of penganak played twin notes $1 / 8$ on the first and second beats, followed by a combination notation of $1 / 8$ and $1 / 16$ on the third beat, followed by playing the $1 / 8$ notation in a row on the fourth beat. Whereas in the second bar, playing the $1 / 4$ notation on the first beat, then resting on the second beat, then playing the $1 / 16$ notation repeatedly on the third beat. On the fourth beat, the musical instrument of penganak play a combination notation of $1 / 16$ and $1 / 8$.

\section{The Percussion Pattern of Sela}

The percussion pattern of the musical instrument of sela is repeatedly performed on each set of rhythmic along the two bars. The percussion pattern of sela is divided into two sounds, namely the sound of drum and pak which plays a $1 / 4$ notation only. The following is the description of the percussion rhythmic of sela.

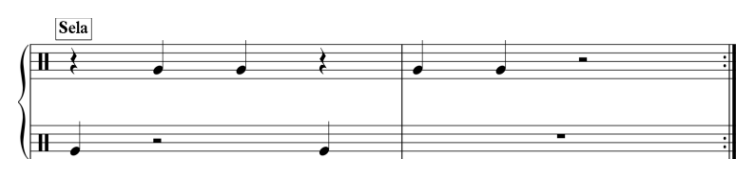

Figure 5. The percussion pattern of Sela

The Figure 5 is the not of the percussion pattern of sela written into two parts, namely the upper and bottom. The upper part is a notation that represents the sound of dung and the bottom part represents the sound of pak. In the upper not, the percussion pattern of sela plays the $1 / 4$ notation on the second and third beat on the first bar and plays the $1 / 4$ notation on the first and second beat on the second bar. While at the bottom of the not music, the percussion pattern of sela plays the $1 / 4$ notation on the first and fourth beat only.

\section{The Percussion Pattern of Terebang Gede (Bass)}

The musical instrument of terebang gede (bass) has a constant pattern, namely by playing full notation on the first beat of each bar. This represents a strong impression at the start of the beat on each bar during the musical performance. The following is the description of percussion rhythmic of terebang gede.

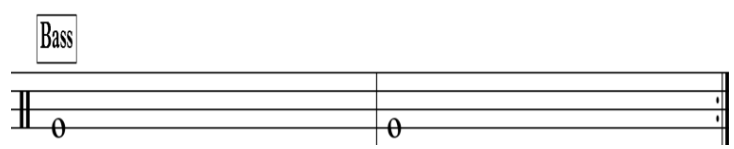

Figure 6. The percussion pattern of Terebang Gede (bass)

The simple percussion pattern referred to as a tool or waditra in the music of terebang gede is a percussion pattern that refers to the standard percussion that has been maintained from generation to generation by Panggung Jati Studio. The existing music players do not develop additional rhythmic patterns as variations as is the case in popular music genres today. The percussion pattern standard wholly is still practiced on the musical instruments of koneng, kempul, penganak (bibit), sela, and bass (terebang gede).

Sinaga (2006) states that traditional music is music that has its origin and roots and it felt like its own by the community in its environment. The life and processing of traditional arts are based on the taste of the supporting community which includes a view of life, values of traditional life, ethical, aesthetic, as well as expressions of environmental culture that are passed on to the next generation. This also happens in the music of Terebang Gede in Panggung Jati Studio, Panggung Jati Village, Serang, Banten.

Maintaining the percussion pattern in the simple music of terebang gede aims to make the beat patterns easy to remember, and also relates to the context of the surrounding environment, where the majority are ordinary people with a lifestyle identical to simplicity. Besides, this simple percussion pattern is also intended so that the taste and meaning contained in sholawat can be conveyed properly and wisely and so that the existing spiritual values and the function of art as a means of spreading the Islamic religion are maintained. This problem seems to be in line with the statement of Juliansyah et al. (2016) that the 
knowledge of musical instruments, both in terms of form, sound, and how to play them, is adapted to the context in human life and the position of the instrument in an ensemble.

How to beat waditra/the musical instrument of terebang gede is done using the right hand. Primarily using the index finger to beat the edge of the raray (leather) to produce a bouncing, light, and loud sound. Besides, you use the palm by tapping it in the middle of the raray (leather) to produce a bouncing, deep, and thick sound.

Philosophically, the use of the index finger is defined as a strong, one, and wise character. This is related to the view of Islam that the index finger at the time of Prophet Ibrahim was symbolized as a figure of tauhid teachings for people who seek the truth (QS: 6/61). Likewise, the use of the right palm has an image of $a d a b$ for something good and positive.

\section{CONCLUSION}

Based on the results of the study, it can be concluded that the music of terebang gede in Panggung Jati Studio, Panggung Jati village, Serang Banten, has interrelated aspects of text and context. The linkages that exist are manifested through the percussion pattern, how to play it, the lyrics of the songs that are sung, and the notation system in the melody of the songs.

The simplicity of the percussion pattern reflects the society's noble values to be maintained and the primacy of the purpose of art as a means of worship. Whereas the way to play musical instruments, song lyrics, and the existing song notation system reflects the integration of messages of religious values and local traditional art culture that are believed by the people of Panggung Jati Village, Banten.

\section{REFERENCES}

Peraturan Gubernur Banten Tentang Rencana Kerja Pemerintah Daerah Provinsi Banten Tahun 2017, 1 (2017).
Chusna, A. (2015). Pentingnya Kegiatan Pembacaan Kitab Al-Barzanji Untuk Mengembangkan Nilai-Nilai Pendidikan Agama Islam di Era Globalisasi di Pondok Pesantren Darussalam Bangunsari Ponorogo. Ponorogo: Institut Agama Islam Negeri Ponorogo.

Dalori, D., Sumaryanto, T., \& Utomo, U. (2019). The Process and Function of Rebana Music Gendukan Jawan As A Communication of Kelompok Informasi Masyarakat (Kim). Catharsis, 8(3), 333-342.

Fauzan, R., \& Nashar, N. (2017). "Mempertahankan Tradisi, Melestarikan Budaya"(Kajian Historis dan Nilai Budaya Lokal Kesenian Terebang Gede di Kota Serang). Candrasangkala: Jurnal Pendidikan dan Sejarah, 3(1), 1-9.

Harjono, R., \& Rachman, A. (2018). Kreativitas Guru Dalam Pembelajaran Ekstrakurikuler Musik Keroncong Di Smp Negeri 1 Karangmoncol. Jurnal Seni Musik, 7(1), 34-47.

Haryanto, J. T. (2015). Relasi Agama dan Budaya dalam Hubungan Intern Umat Islam. Jurnal SMART (Studi Masyarakat, Religi, dan Tradisi), 1(1), 41-54.

Hood, M. (1957). Training and Playing in Ethnomusicology. Ethnomusicology Newsletter, 11(1).

Juliansyah, J., Syam, C., \& Indrapraja, D. K. (2016). Kajian Etnomusikologi Alat Musik Alo' Galing di Kecamatan Sambas Kabupaten Sambas. Jurnal Pendidikan Dan Pembelajaran Khatulistiwa, 5(2), 1-11.

Khasanah, N., Nurhidayati, M., \& Pamungkas, R. (2020). Penerapan Budaya Pengajaran Ala Pesantren di Lingkungan Dusun Sumberejo Lembeyan Wetan Magetan. Dimas: Jurnal Pemikiran Agama Untuk Pemberdayaan, 20(1), 53-64.

Khasbullah, A., Ismunandar, I., \& Muniir, A. (2005). Kajian Musikologi Ragam Pola Tabuhan Tradisional Tar di Kelurahan Sungai Jawi Dalam Kota Pontianak. Jurnal Pendidikan Dan 
Pembelajaran Khatulistiwa, 8(3), 1-9.

Kubarsah, U. (1994). Waditra Mengenal Alat-Alat Kesenian Darah Jawa Barat. Bandung: Sampurna.

Moleong, L. J. (2017). Metodologi Penelitian Kualitatif. Bandung: Rosda.

Mulyana, Y. (2001). Dimensi Gerakan dalam Proses Pembentukan Propinsi Banten. Jurnal Ilmu Sosial dan Ilmu Politik, 5(1), 61-90.

Nugraha, F. (2018). Kesenian Terbang Gede dalam Tradisi Ngarak Panjang Mulud di Masyarakat Banten. Jurnal Budaya Etnika, 2(1).

Nurhasanah, A., \& Maryuni, Y. (2012). Revitalisasi Nilai Budaya dan Sejarah Bahari Banten Sebagai National Character Building. 2(January), 978-979.

Rachman, A., \& Pribadi, S. E. (2019). Kroncong Music in Semarang: A Process of Enculturation. Ijal, 4(2), 1-9.

Rachman, A., \& Utomo, U. (2018). "Sing Penting Keroncong": Sebuah Inovasi Pertunjukkan Musik Keroncong di Semarang. Jurnal Pendidikan Dan Kajian Seni, 3(1).

Rachman, A., \& Utomo, U. (2019). The Rhythm Pattern Adaptation of Langgam Jawa in Kroncong. Advances in Social Science, Education and Humanities Research, Volume 276 2nd International Conference on Arts and Culture (ICONARC 2018), 276(Iconarc 2018), 99-101.

Ramadhani, F. A., \& Rachman, A. (2019). Resistensi Musik Keroncong di Era Disrupsi: Studi Kasus pada O.K Gita Puspita di Kabupaten Tegal. Musikolastika: Jurnal Pertunjukan Dan Pendidikan Musik, 1(1), 41-51.

Said, H. A. (2016). Islam dan Budaya Di Banten: Menelisik Atraksi Debus dan Tradisi Panjang Maulid. Kalam: Jurnal Studi Agama dan Pemikiran Islam, 10(1), 109-138.

Simeon, J. J. C. (2015). The U9 Xylophone:
An Innovation in Music Classroom Teaching. Wacana Seni Journal of Arts Discourse, 14, 147-165.

Simeon, J. J. C., On, L. K., Baxter, I. S., Saudik, M., Ahmad, S., \& Suan, C. L. (2017). Traditional Musical Instruments and Dance Music of the Lundayeh of Sabah. Wacana Seni, 16, 103-133.

Sinaga, S. S. (2001). Akulturasi Kesenian Rebana (The Acculturation of the Art of Rebana). Harmonia: Journal of Arts Research and Education, 2(3), 72-83.

Sinaga, S. S. (2006). Fungsi dan Ciri Khas Kesenian Rebana di Pantura Jawa Tengah (Function and Characteristic of Rebana in the Beach Region of Central Java). Harmonia: Journal of Arts Research and Education, 7(3).

Sugiyono. (2016). Metode Penelitian dan Pengembangan. Jakarta: Elfabeta.

Suprihatin, E. W., \& Pratamawati, D. (2019). Conservation Strategy in Preserving The Local Image Existence of Wayang Topeng. Harmonia: Journal of Arts Research and Education, 19(2), 179-184.

Viedar, G. M. (2018). Pembelajaran Seni Terebang Gede Dalam Kegiatan Ekstrakulikuler di SMP 13 Kota Serang. Bandung: Universitas Pendidikan Indonesia.

Wicaksono, H. Y. (2019). Weak of Effects of Music Education in The Establishment of Characters. Harmonia: Journal of Arts Research and Education, 19(2), 172-178.

Widyasari, N. (2014). Peranan Debus Dalam Pembinaan Budaya Kewarganegaraan (Civic Culture) Pada Masyarakat Banten. Bandung: Universitas Pendidikan Indonesia.

Zahrotul, F., \& Rachman, A. (2020). Aransemen Vokal Sebagai Identitas O.K Congrock 17 di Semarang. Gondang : Jurnal Seni Dan Budaya, 4(1), 38-46. 